\title{
Nitrogen Nutrition of Young Citrus Fruit with Special Reference to Asparagine ${ }^{1}$
}

\author{
Tadashi $\mathrm{KATO}^{2}$ \\ Shikoku National Agricultural Experiment Station, Zentsuji, kagawa 765
}

\begin{abstract}
Summary
Asparagine was the predominant constituent of the free amino acids in young fruit of Citrus unshiu Marc. In early August, asparagine increased exponentially with total $\mathrm{N}$ in the fruit peel, suggesting that it can be used as an indicator of the nitrogen status of young fruit. ${ }^{15} \mathrm{~N}$ data showed that the primary assimilation of ammonium was catalyzed by glutamine synthetase, and asparagine was also actively formed in the early stages of nitrogen assimilation. Nitrate assimilation occurred to a lesser extent than ammonium assimilation in the hour-order experiment using excised fruit. In the day-order experiment, however, nitrate taken up via the roots was assimilated in greater amounts than ammonium. ${ }^{14} \mathrm{C}$-asparagine was rapidly metabolized to different compounds, such as aspartate, acidic and neutral compounds, and alcohol-insoluble compounds. However, considerably less $\mathrm{CO}_{2}$ was formed from asparagine than from aspartate. Our data show that asparagine is not a dead-endproduct but plays an important role in the supply of both $\mathrm{N}$ and $\mathrm{C}$ for the synthesis of other amino acids and protein in young fruit.
\end{abstract}

\section{Introduction}

There are many reports on the amino acid composition of juice from nearly mature and mature citrus fruits, but there are very few concerning young fruit. The free amino acid composition of young fruit (in mid-July) showed a marked difference from that of mature one. Young fruit were characterized by a large amount of asparagine, which amounted to $80 \%$ or more of the total free amino acids on a molar basis(7).

${ }^{15} \mathrm{~N}$ tracer studies have shown that nitrate taken up via roots is transported rapidly to the fruit and is assimilated to amino acids (7). On the other hand, in a tree fed with ammonium, asparagine is the predominant $\mathrm{N}$-transport compound (9), showing that asparagine serves as the main source of $\mathrm{N}$ for the development of fruit. Similar results have been reported for legumes. In legumes, asparagine is the main constituent of the free amino acid pools of various plant parts

1 Received for publication June 30, 1982.

2 Present address : National Grassland Research Institute, Nishinasuno, Tochigi 329-27.
$(1,2,13,15)$, and is also the major $\mathrm{N}$ compound in the phloem sap of fruiting shoot (14). Pate et al. (14) suggest that aspara gine is one of the main sources of $\mathrm{N}$ for protein formation in developing legume fruit.

Although the path of asparagine utiliza tion is not clear, two routes for asparagine br eakdown have been suggested for several plant species $(3,12)$; one catalyzed by asparaginase and the other by asparagine transaminase. For citrus plants, there is no information on asparagine utilization.

To learn more about asparagine forma tion and utilization in citrus fruit, the assimilation of ${ }^{15} \mathrm{~N}$-nitrate and ${ }^{15} \mathrm{~N}$-ammonium, and also the fate of ${ }^{14} \mathrm{C}$-asparagine and ${ }^{14} \mathrm{C}$-as partate were examined.

\section{Materials and Methods}

\section{Experiment 1}

To clarify changes in the composition and pool sizes of free amino acids during $f$ ruit development, young fruit were harvested from a 16-year-old satsuma mandarin tree (Citrus unshiu Marc.) several times during the summer of 1977, and analyzed. In a ddi- 
tion, on August 3, 1977, the asparagine content in peel and the $\mathrm{N}$ content in peel and leaves were analyzed for 14 16-year-old trees grown with different $\mathrm{N}$ levels and the relationships between them were investigated.

\section{Experiment 2}

The assimilation of ${ }^{15} \mathrm{~N}$-nitrate and ${ }^{15} \mathrm{~N}$ ammonium in excised fruit was examined. On June 15, 1978, young fruit were harvested from a 17-year-old tree grown in soil culture under normal dressing. The basal $1 \mathrm{~cm}$ of peduncle was cut under water, and ${ }^{15} \mathrm{~N}$ solution $(56 \mathrm{mM}$ potassium nitrate and $28 \mathrm{mM}$ ammonium sulfate, 95 atom \%) were supplied to the fruit via the cut end in a controlled chamber at a relative humidity of about $80 \%$. The fruit were incubated at $30^{\circ} \mathrm{C}$ under illumination of $22 \mathrm{~W} / \mathrm{m}^{2}$ from white fluorescent lamps, and analyzed for $\mathrm{N}$ and isotopic abundance after 1,2 and $5 \mathrm{~h}$ of incubation.

\section{Experiment 3}

The incorporation of ${ }^{15} \mathrm{~N}$ into asparagine was examined in intact fruit on the tree. Four-year-old trees grown in gravel culture were fed with $16 \mathrm{mM} \mathrm{K}^{15} \mathrm{NO}_{3}(10$ atom \%) or $8 \mathrm{mM}\left({ }^{15} \mathrm{NH}_{4}\right)_{2} \mathrm{SO}_{4}(10$ atom \%) for 5 days, beginning on June 23,1975 . The fruit were harvested after 2 and 5 days of feeding, and assayed for total N, amino acids and nitrate, and also for their isotopic abundances.

Analyses of nitrogenous components and isotopic abundances

Total $\mathrm{N}$ was assayed using the Kjeldahl method. Nitrate and amino acids were extracted with $70 \%$ ethylalcohol containing $100 \mathrm{mM} \mathrm{KCl}$. Nitrate was measured using Devalda's alloy and microdiffusion apparatus, while amino acids were determined with an amino acid autoanalyzer with a lithium buffer system after removing alcohol under a vacuum and bufferizing. The procedure for the separation of nitrogenous compounds for the determination of isotopic abundances is described elsewhere $(4,5,6,7) .{ }^{15} \mathrm{~N}$ abundances were determined spectrophotometrically.

Experiment 4

To examine how asparagine is utilized,
${ }^{14} \mathrm{C}$-compounds were applied to young fruits and their fates were followed. Fruit (around $32 \mathrm{~g}$ each) were harvested from the same tree as described in Experiment 2 on August 3 , 1978. In each fruit, a hole $(7 \mathrm{~mm}$ in diameter and 3 to $4 \mathrm{~mm}$ in depth) was made at the calyx end with a corkborer. Five $\mu$ moles each of $\mathrm{L}$-asparagine- $\mathrm{U}-{ }^{14} \mathrm{C}$ and $\mathrm{L}$ aspartic acid- $\mathrm{U}-{ }^{14} \mathrm{C}$ (New England Nuclear Corporation, $5 \mu \mathrm{Ci}, 0.1 \mathrm{ml}$ ) were applied to the holes with $0.1 \mathrm{ml}$ of $50 \mathrm{mM}$ sucrose. Two fruit were used for each compound. They were then put in a glass vessel with a lid (90 $\mathrm{mm}$ in diameter and $60 \mathrm{~mm}$ in depth) connected to double $\mathrm{CO}_{2}$-traps containing a mixture of monoethanolamine and methylalcohol $(2: 1, \mathrm{~V} / \mathrm{V})$ and incubated at $30^{\circ} \mathrm{C}$ and air flow rate of about $50 \mathrm{ml} / \mathrm{min}$. After 5 and $10 \mathrm{~h}$ of incubation, the fruit were homogenized with $120 \mathrm{ml}$ of $80 \%$ ethylalcohol, and centrifuged. An aliquot of the supernatant was treated with active charcoal and then with amberlite IR $120\left(\mathrm{H}^{+}\right)$resin. Thus, it was separated into two fractions of the acidic and neutral components and the cationic components. Ten $\mathrm{mg}$ of the dried alcohol-insoluble fraction was digested with a $1: 2$ solution of $\mathrm{H}_{2} \mathrm{O}_{2}(30 \%)$ and $\mathrm{HClO}_{4}(60$ $\%$ ). The radioactivities of these three fractions were measured by scintillation spectrometry after dissolving in a mixture of toluene-ethylcellosolve-PPO $\quad(50: 30: 0.3$, $\mathrm{V} / \mathrm{V} / \mathrm{W}$ ). Further, the amino acids in the cationic fraction were separated out by twodimensional paper chromatography. The piece of the paper containing each amino acid was cut out, put into a vial, and its radioactivity was measured.

\section{Results}

\section{$V$ ariation in amino acid content}

Asparagine was the predominant free amino acid in early July fruit (Fig. 1), accounting for $65 \%$ of total amino acids on a molar basis and $79 \%$ on a $\mathrm{N}$ basis. Asparagine accounted for a far higher percentage of total amino acids in the peel than in juice vesicles. Asparagine content decreased during the development of fruit in both tissues. Aspartate, serine, proline and other amino 


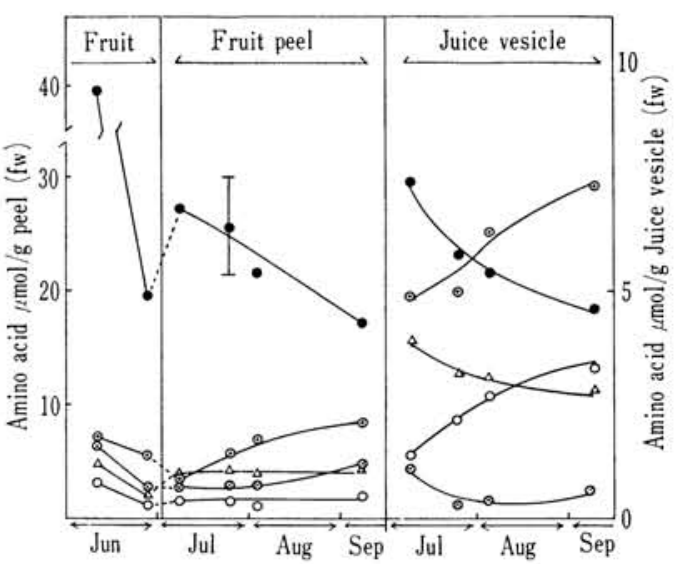

Fig. 1. Changes in major free amino acid contents in young fruit. (๑): asparagine. (0): aspartic acid. $(\Delta)$ : serine. $(\otimes)$ : proline. $(\odot)$ : others.

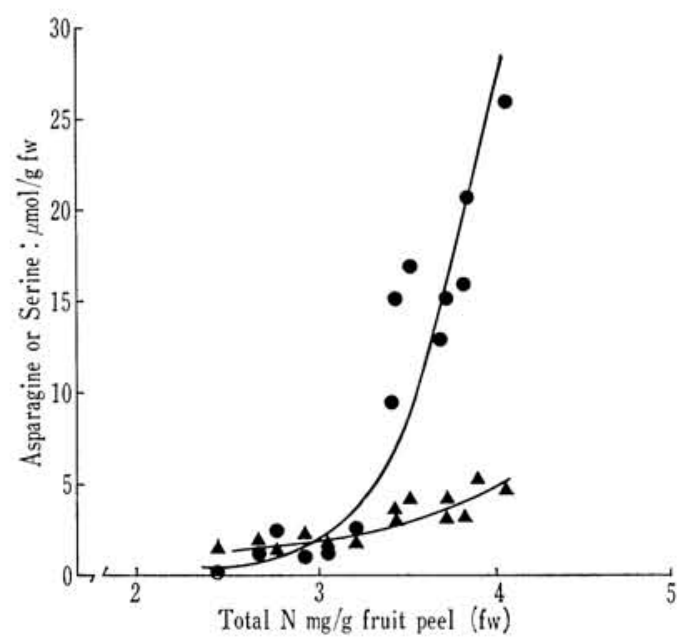

Fig. 2. Relationship between asparagine $(\bullet)$ and serine ( $\mathbf{\Lambda}$ ) content and $\mathrm{N}$ content in young fruit peel.

acids in the fruit peel showed no marked change. In juice vesicles, however, aspartate increased slowly until September, whereas serine and proline decreased slowly.

The relationship between asparagine and total $N$ content

The relationship between asparagine and total $\mathrm{N}$ content in the fruit peel is shown in Fig. 2. Serine was the second most important constituent, and its relation to total $\mathrm{N}$ is shown for comparison. The relationship between total $\mathrm{N}$ and asparagine was exponential. On a fresh weight basis, asparagine was present in smaller amounts than serine

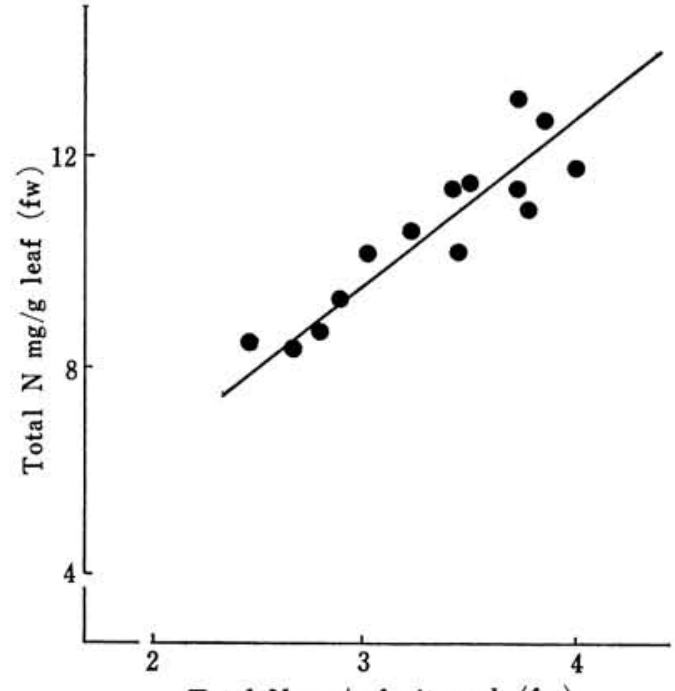

Total $\mathrm{N} \mathrm{mg/g}$ fruit peel (fw)

Fig. 3. Relationship between total $\mathrm{N}$ content in leaves and young fruit peel.

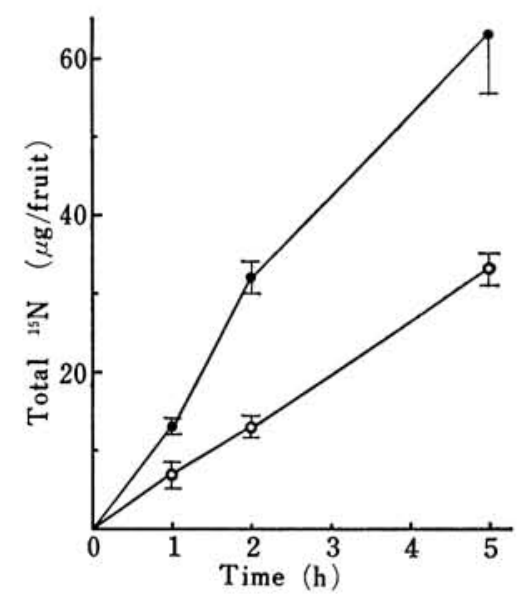

Fig. 4. Time course of incorporation of ${ }^{15} \mathrm{~N}$-ammonium $(O)$ and ${ }^{15} \mathrm{~N}$-nitrate $(\bullet)$ into the excised fruit. Vertical bars mean SD.

at total $\mathrm{N}$ content below $3.2 \mathrm{mg} / \mathrm{g}$, but at total $\mathrm{N}$ content above $3.4 \mathrm{mg} / \mathrm{g}$, asparagine increased markedly over serine. Serine also increased exponentially with total $\mathrm{N}$, although, the increasing rate was very low. Total $\mathrm{N}$ content in the fruit peel also showed a linear relationship with total $\mathrm{N}$ content of the leaves (Fig. 3). Thus, asparagine content was related exponentially not only with the $\mathrm{N}$ content of fruit, but also with that of leaves.

${ }^{15} \mathrm{~N}$ assimilation in excised and intact 


\section{fruit}

Incorporation of source ${ }^{15} \mathrm{~N}$ into excised fruit increased at a constant rate during the experimental period regardless of $\mathrm{N}$ forms (Fig. 4). The rate of incorporation, however, was nearly 3 times higher for nitrate than ammonium $5 \mathrm{~h}$ after the start of feeding. this difference was probably caused by the differential mobility of source $\mathrm{N}$ in the transpirational stream in the xylem. Incorporation of ${ }^{15} \mathrm{~N}$ in to the main amino acids was clearly higher for ammonium feeding than nitrate feeding (Table 1 and 2). This means probably that nitrate is converted to amino acids after reduction to ammonium. In the fruit fed with ${ }^{15} \mathrm{~N}$-ammonium, labelling by ${ }^{15} \mathrm{~N}$ was highest in glutamine amide- $\mathrm{N}$, followed by aspartate. Glutamine amino-N, glutamate and alanine had relatively high abundances of ${ }^{15} \mathrm{~N}$, while much less asparagine amide$\mathrm{N}$, proline and arginine were labelled. In the fruit fed with ${ }^{15} \mathrm{~N}$-nitrate, isotopic abundances were comparatively low, on the whole, compared with the fruit fed with ammonium. Nevertheless, the labelling patterns were similar. Quantitatively, for both $\mathrm{N}$ forms, glutamine was the major component newly synthesized with source $\mathrm{N}$, followed by aspartate, glutamate and asparagine. On the other hand, proline and arginine were formed in negligible amounts (Table 2).
The incorporation of source $\mathrm{N}$ into the nitrogenous components of intact fruit on the tree is shown in Table 3. The uptake of source $\mathrm{N}$ was clearly higher for nitrate than ammonium, and further, conversion to organic components was also higher for nitrate. This differs from the result for excised fruit. The discrepancy seems to have been caused by the difference in the experimental period. ${ }^{15} \mathrm{~N}$ in asparagine accounted for $65 \%$ and $72 \%$ of the total ${ }^{15} \mathrm{~N}$ in amino acids after 2 and 5 days, respectively, in ammonium-fed trees, and $58 \%$ and $68 \%$, respectively, in nitrate-fed trees. This shows that asparagine is actively synthesized with the source $\mathrm{N}$ and pooled. ${ }^{15} \mathrm{~N}$ incorporated into the residual components other than amino acids and nitrate accounted for $50 \%$ and $83 \%$ of total ${ }^{15} \mathrm{~N}$ after 2 and 5 days, respectively, in both $\mathrm{N}$ forms. A large part of the residual components is considered to be protein. Thus, protein seems to be actively formed with the source $\mathrm{N}$.

In the fruit from the trees fed with ${ }^{15} \mathrm{~N}-$ ammonium, labelled nitrate was found. Unpublished data from our laboratory showed that ${ }^{15} \mathrm{~N}$-nitrate was formed in the gravel bed after $24 \mathrm{~h}$ after ${ }^{15} \mathrm{~N}$-ammonium application. Probably, ${ }^{15} \mathrm{~N}-$ nitrate in the fruit was not formed from ${ }^{15} \mathrm{~N}$-ammonium in any tissue after uptake by the roots, but originated from labelled nitrate formed micro-

Table 1. Time course of ${ }^{15} \mathrm{~N}$ abundance (atom \% excess) of amino acids in excised fruit fed with ${ }^{15} \mathrm{~N}$-ammonium and ${ }^{15} \mathrm{~N}$-nitrate (Exp. 2)

\begin{tabular}{|c|c|c|c|c|c|}
\hline \multirow{2}{*}{ Amino acid } & \multicolumn{3}{|c|}{ Ammonium feeding } & \multicolumn{2}{|c|}{ Nitrate feeding } \\
\hline & $1 \mathrm{~h}^{\mathrm{z}}$ & $2 \mathrm{~h}$ & $5 \mathrm{~h}$ & $2 \mathrm{~h}$ & $5 \mathrm{~h}$ \\
\hline Aspartate & $0.14^{\gamma}$ & 0.99 & 2. $64 \pm 0.10^{\mathrm{x}}$ & 0.08 & $0.15 \pm 0.02$ \\
\hline Glutamate & 0.15 & 0.96 & $1.89 \pm 0.09$ & 0.09 & $0.12 \pm 0.01$ \\
\hline Serine & 0,13 & 0.21 & $0.95 \pm 0.07$ & 0.01 & $0.07 \pm 0.01$ \\
\hline Glycine & - & 0.13 & 0.49 & 0.00 & - \\
\hline Alanine & 0.05 & 0.58 & $1.56 \pm 0.06$ & 0.01 & $0.07 \pm 0.03$ \\
\hline$\gamma$-Aminobutyrate & 0.03 & 0.18 & 0.53 & 0.00 & - \\
\hline Proline & 0.03 & 0.04 & $0.04 \pm 0.01$ & 0.01 & $0.02 \pm 0.01$ \\
\hline Arginine & 0.01 & 0.03 & $0.28 \pm 0.01$ & 0.00 & 0.01 \\
\hline \multicolumn{6}{|l|}{ Glutamine } \\
\hline S amide & 0.62 & 1.58 & 4. $87 \pm 0.17$ & 0.22 & $0.26 \pm 0.05$ \\
\hline$\{$ amino & 0.08 & 0.62 & $3.53 \pm 0.12$ & 0.02 & $0.08 \pm 0.03$ \\
\hline \multicolumn{6}{|l|}{ Asparagine } \\
\hline f amide & 0.02 & 0.04 & $0.11 \pm 0.02$ & 0.01 & $0.01 \pm 0.01$ \\
\hline$\{$ amino & 0.00 & 0.01 & $0.06 \pm 0.01$ & 0.00 & $0.01 \pm 0.01$ \\
\hline
\end{tabular}

${ }^{\mathrm{z}}$ Hours after feeding. ${ }^{\mathrm{Y}}$ Single determination. ${ }^{\mathrm{x}}$ Mean $\pm \mathrm{SE}$ of 3 fruit. 
Table 2. Time course of content of newly synthesized amino acids ( $\mathrm{nmol} / \mathrm{g} \mathrm{fw}$ ) in excised fruit fed with ${ }^{15} \mathrm{~N}$-ammonium and ${ }^{15} \mathrm{~N}$-nitrate (Exp. 2). Newly synthesized amino acid (NSA) means pool size of amino acid labelled with source N. Calculation was performed as follows :

$\mathrm{NSA}=\frac{{ }^{15} \mathrm{~N} \text { atom } \% \text { excess in amino acid }}{94.63} \times$ pool size of amino acid $(\mathrm{n}$ mol)

\begin{tabular}{|c|c|c|c|c|c|}
\hline \multirow{2}{*}{ Amino acid } & \multicolumn{3}{|c|}{ Ammonium feeding } & \multicolumn{2}{|c|}{ Nitrate feeding } \\
\hline & $1 \mathrm{~h}^{2}$ & $2 \mathrm{~h}$ & $5 \mathrm{~h}$ & $2 \mathrm{~h}$ & $5 \mathrm{~h}$ \\
\hline Aspartate & 1. $61^{Y}$ & 12.9 & $42.4 \pm 5.60^{\mathrm{x}}$ & 1.68 & 2. $62 \pm 0.47$ \\
\hline Glutamate & 1.64 & 13. 2 & $36.3 \pm 7.20$ & 1.93 & 2. $68 \pm 0.22$ \\
\hline Serine & 1.09 & 8.0 & $24.6 \pm 3.61$ & 0.43 & 2. $11 \pm 0.35$ \\
\hline Glycine & - & 0.54 & 2. 6 & 0.01 & - \\
\hline Alanine & 0.22 & 2. 24 & $7.7 \pm 0.71$ & 0.13 & 0.82 \\
\hline$\gamma$-Aminobutyrate & 0.10 & 1. 23 & 2.1 & 0.07 & - \\
\hline Proline & 0.88 & 2. 89 & $1.2 \pm 0.31$ & 0.75 & $0.56 \pm 0.13$ \\
\hline Arginine & 0.00 & 0.19 & $1.1 \pm 0.06$ & 0.00 & 0.04 \\
\hline \multicolumn{6}{|l|}{ Glutamine } \\
\hline \{ amide & 10.3 & 30.4 & $64.8 \pm 3.21$ & 2.66 & $3.90 \pm 0.74$ \\
\hline$\{$ amino & 1. 37 & 11.9 & $42.3 \pm 3.40$ & 0.18 & $0.84 \pm 0.34$ \\
\hline \multicolumn{6}{|l|}{ Asparagine } \\
\hline \{ amide & 4. 10 & 10.0 & $31.0 \pm 3.45$ & 2. 15 & 2. $41 \pm 1.36$ \\
\hline$\{$ amino & 0.00 & 2. 51 & $15.9 \pm 3.01$ & 0.00 & 1. $57 \pm 1.50$ \\
\hline
\end{tabular}

Table 3. Incorporation of source ${ }^{15} \mathrm{~N}$ into various components in young fruit (Exp. 3).

\begin{tabular}{|c|c|c|c|c|c|}
\hline \multirow{3}{*}{ Source } & \multirow{3}{*}{ Component } & \multicolumn{4}{|c|}{ Time (day) } \\
\hline & & \multicolumn{2}{|l|}{2} & \multicolumn{2}{|l|}{5} \\
\hline & & (atom ${ }^{15} \mathrm{~N}$ excess) & ${ }_{(\mu \mathrm{g} / \mathrm{g} \mathrm{fw})}$ & (atom ${ }^{15} \mathrm{~N}$ excess) & $\begin{array}{c}{ }^{15} \mathrm{~N} \\
(\mu \mathrm{g} / \mathrm{g} \mathrm{fw})\end{array}$ \\
\hline \multirow{4}{*}{${ }^{15} \mathrm{~N}-$ Ammonium } & Total N & 0.01 & 6.68 & 0.09 & 93.0 \\
\hline & Asparagine & 0.06 & 2.04 & 0.27 & 9.94 \\
\hline & Other amino acids & 0.05 & 1.12 & 0.35 & 3.82 \\
\hline & $\mathrm{NO}_{3}^{-}$ & 0.10 & 0.31 & 0.70 & 1.51 \\
\hline \multirow{4}{*}{${ }^{15} \mathrm{~N}-$ Nitrate } & Total N & 0.03 & 16.5 & 0.23 & 244 \\
\hline & Asparagine & 0.06 & 2. 37 & 0.59 & 21.5 \\
\hline & Other amino acids & 0.11 & 1.74 & 0.75 & 10.2 \\
\hline & $\mathrm{NO}_{3}^{-}$ & 0.84 & 3. 68 & 1.50 & 8.75 \\
\hline
\end{tabular}

Table 4. Conversion ${ }^{2}$ of ${ }^{14} \mathrm{C}$-asparagine and ${ }^{14} \mathrm{C}$-aspartate applied to young fruits after $10 \mathrm{~h}$ of incubation (Exp. 4).

\begin{tabular}{|c|c|c|c|c|c|}
\hline \multirow{2}{*}{${ }^{14} \mathrm{C}$-compound } & \multirow{2}{*}{$\mathrm{CO}_{2}$} & \multicolumn{2}{|c|}{ Alcohol-soluble fraction } & \multirow{2}{*}{$\begin{array}{c}\text { Alcohol-insoluble } \\
\text { fraction }\end{array}$} & \multirow{2}{*}{ Sum } \\
\hline & & Cationic & Acidic and Neutral & & \\
\hline Aspartate & 16.5 & 27.5 & 17.9 & 33. 2 & 95.1 \\
\hline Asparagine & 6.3 & 43.8 & 14.9 & 28.5 & 93.5 \\
\hline
\end{tabular}

${ }^{2}$ Expressed as percentages of the initial radioactivity.

biologically from ${ }^{15} \mathrm{~N}$-ammonium in the nutrient solution.

\section{Metabolism of ${ }^{14} \mathrm{C}$-compounds}

${ }^{14} \mathrm{C}$-aspartic acid and ${ }^{14} \mathrm{C}$-asparagine were applied to excised fruit in early August, when asparagine was decreasing with a concomitant increase of aspartate (Fig. 1). The degradation and conversion of ${ }^{14} \mathrm{C}$-substrate are shown in Table 4 and 5 . More than $90 \%$ of the initial radioactivity in both substrates was recovered in $\mathrm{CO}_{2}$, and alcohol-soluble and -insoluble fractions. In the aspartatefed fruit, $33 \%$ of the initial radioactivity was incorporated into the alcohol-insoluble component, $18 \%$ was metabolized to acidic and neutral components, and $17 \%$ was found 
Table 5. Conversion ${ }^{2}$ of ${ }^{14} \mathrm{C}$-asparagine and ${ }^{14} \mathrm{C}$-aspartate to different amino acids in young fruits (Exp. 4)

\begin{tabular}{|c|c|c|c|c|}
\hline \multirow{2}{*}{ Amino acid } & \multicolumn{2}{|c|}{${ }^{14} \mathrm{C}$-asparag ine } & \multicolumn{2}{|c|}{${ }^{14} \mathrm{C}$-aspartate } \\
\hline & $5 h^{Y}$ & $10 \mathrm{~h}$ & $5 \mathrm{~h}$ & $10 \mathrm{~h}$ \\
\hline Aspartate & 370 & 660 & 9,100 & 5,200 \\
\hline Glutamate & 20 & 50 & 70 & 190 \\
\hline Serine & 35 & 50 & 190 & 270 \\
\hline Asparagine & 9,000 & 8,200 & 90 & 230 \\
\hline Alanine & 130 & 230 & 120 & 530 \\
\hline$\gamma$-Aminobuty rate & 85 & 240 & 630 & 1,580 \\
\hline Proline & 10 & 45 & 95 & 165 \\
\hline Others & 110 & 190 & 320 & 790 \\
\hline
\end{tabular}

in $\mathrm{CO}_{2}$. While, in the asparagine-fed fruit, incorporations into each of the alcohol-insoluble fraction and the acidic and neutral fraction were slightly lower, but conversion to $\mathrm{CO}_{2}$ was considerably lower.

Aspartate and asparagine were metabolized to various amino acids (Table 5). In the aspartate-fed fruit, the highest level of radioactivity was found in $\gamma$-aminobutyrate, except for aspartate. In the asparagine-fed fruit, the highest radioactivity was found in aspartate, except for asparagine, showing that the asparagine-utilizing route catalized by asparginase is operating.

\section{Discussion}

Young fruit were found to have a large pool of asparagine (Fig. 1). The pool size was related exponentially with the $\mathrm{N}$ level of the fruit (Fig. 3). This indicates that asparagine can be used as an indicator of the $\mathrm{N}$ status of young fruit.

It has been considered that the glutamate dehydrogenase plays an important role in the early stage of $\mathrm{N}$ assimilation. Recently, however, many data show that the incorporation of ammonium into amino acids proceeds via glutamine synthetase (GS) and glutamine: $\alpha$-oxoglutarate aminotransferase (GOGAT) assimilatory pathway $(11,17)$. In citrus fruit, ${ }^{15} \mathrm{~N}$-ammonium was mainly incorporated in to glutamine-amide N (Table 2 ), showing that it is assimilated to amino acids via the GS/GOGAT pathway. Streeter (16) has shown that asparagine is formed from aspartate and glutamine, and this reaction is catalyzed by a glutamine-depend- ent asparagine synthetase. In the present experiment, the amount of ${ }^{15} \mathrm{~N}$ incorporated into asparagine-amide $\mathrm{N}$ was half that of glutamine-amide N. However, the amount of newly synthesized amino acids against time showed that glutamine-amide $\mathrm{N}$ increased in a convex curve and asparagine-amide $\mathrm{N}$ in a concave one. Furthermore, in intact fruits on the tree fed with nitrate, labelled asparagine increased in a concave curve and accounted for $58 \%$ and $68 \%$ of total labelled amino acid at 2 and 5 days, respectively. This shows that in citrus fruits asparagine is synthesized predominantly, and its formation is catalyzed by a glutamine-dependent asparagine synthetase. Leaves show very weak activity in asparagine formation as compared to glutamine formation(8). Thus, young fruits are characterized by active formation of asparagine.

For a long time asparagine was not considered to occur in protein. Recently, however, asparagine was detected in digested protein, and further, the enzyme involved in the incorporation of asparagine into protein, asparaginyl-tRNA synthetase, has been isolated from many higher plant species(10). In the present experiments, $28.5 \%$ of the radioactivity of source asparagine was found in the alcohol-insoluble fraction after $10 \mathrm{~h}$ of incubation, showing that ${ }^{14} \mathrm{C}$ originated from asparagine is actively incorporated into newly synthesized protein.

Asparagine has two degradation routes(12); one is catalyzed by the enzyme asparaginase and the other by transaminase. In the asparagine-fed fruit, the highest radioactivity was found in aspartate, except for asparagine (Table 5 ), showing that one possible route of asparagine breakdown is catalyzed by asparaginase. According to our unpublished data on the conversion of ${ }^{14} \mathrm{C}$-compounds other than asparagine and aspartate into different free amino acids in citrus fruits, both $\gamma$-aminobutyrate and succinate are metabolized mostly to aspartate, but the conversion of succinate to $\gamma$-aminobutyrate is negligible. Both our present results and our unpublished data show that in citrus fruit $\gamma$-aminobutyrate converts to aspartate 
via succinate and other compounds belonging to the TCA cycle, but the reverse conversion of aspartate to $\gamma$-aminobutyrate via succinate is unlikely to proceed.

The conversion of asparagine to acidic and neutral components occurred to about the same extent as that of aspartate, but its conversion to $\mathrm{CO}_{2}$ was less. Therefore, one or more metabolic pathways for asparagine, other than that catalyzed by the enzyme asparaginase, also exist. The present data are not thoroughgoing enough to show which pathway is the main one for asparagine utilization.

\section{Literature cited}

1. Atkins, C.S., J.S. PATE and P. J. Sharkey. 1975. Asparagine metabolism-Key to the nitrogen nutrition of developing legume seeds. Plant Physiol. $56: 807-812$.

2. BAUER, A., A. A. URGUHART and K. W. JOY. 1977. Amino acid metabolism of pea leaves: Diurnal changes and amino acid synthesis from ${ }^{15} \mathrm{~N}$-nitrate. Plant Physiol. 59:915919.

3. IRELAND, R. J. and K. W. Joy. 1981. Two routes for asparagine metabolism in Pisum sativum L. Planta $191: 289-292$.

4. KATO, T. 1974. Determination of ${ }^{15} \mathrm{~N}$ abundance in ammonium, nitrate, amide and amino acids in plant extracts. Bull. shikoku Agric. Exp. Stn. 28:151-157 (In Japanese)

5. KaTO, T. 1975. Determination of ${ }^{15} \mathrm{~N}$ abundance in amino acids separated by paper chromatography. J. Sci. Soil Manure 46: 66-67. (In Japanese)

6. KATO, T. 1979. Determination of ${ }^{15} \mathrm{~N}$ abundance in glutamine separated by paper chromatography. J. Sci. Soil Manure $50: 169-170$. (In Japanese)

7. Kato, T. 1980. Nitrogen assimilation in citrus trees. 1. Ammonium and nitrate assimilation by intact roots, leaves and fruits. Physiol. Plant. 48: 416-420.

8. KATO, T. 1980. Nitrogen assimilation by a citrus tree. 2. Assimilation of labelled ammonium and nitrate by detached leaves in light and dark. Physiol. Plant. $50: 304-308$.

9. KATO, T. 1981. Major nitrogen compounds transported in xylem vessels from roots to top in citrus trees. Physiol. Plant. 52 : 275279.

10. LEA, P. J. and L. FowDEn. 1973. Amino acid substrate specificity of asparaginyl-, aspartyland glutamyl-tRNAsynthetase isolated from higher plants. Phytochem. 12:1903-1916.

11. LEA, P. J. and B. J. MIFLIN. 1974. Alternative route for nitrogen assimilation in higher plants. Nature 251: 614-616.

12. LEA, P. J. and L. FowDEN. 1975. Asparagine metabolism in higher plants. Biochem. Physiol. Pflanzen $168: 3-14$.

13. MCCLURE, P.R. and D. W. ISRAEL. 1979. Transport of nitrogen in the xylem of soy. bean plants. Plant Physiol. 64: 411-416.

14. PATE, J. S., P. J. SharkeY and O. A. M. LeWIS. 1975. Xylem to phloem transfer of solutes in fruiting shoots of legumes, studied by a phloem bleeding technique. Planta 122 : 1126.

15. PATE, J. S., C. A. AtKins, D. F. HeRridge and D. B. LAYZELL. 1981. Synthesis, storage, and utilization of amino compounds in white lupin (Lupinus albus L.). Plant Physiol. $67: 37-42$.

16. STREETER, J. G. 1973. In vivo and in vitro studies on asparagine biosynthesis in soybean seedling. Arch. Biochem. Biophys. 157 : 613624.

17. WeISSMAN, G.S. 1972. Influence of ammonium and nitrate nutrition on enzymatic activity in soybean and sunflower. Plant Physiol. $49: 138-141$.

ミカン幼果の窒素栄養, 特にアスパラギン代謝について

\author{
加 藤 忠 司
}

農林水産省四国農業試験場 765 香川県善通寺市

\author{
摘 要 \\ 6月から 8 月にかけてのウンシュウミカンの幼果は多 \\ 量のアスパラギンを含有する. そこで果実の窒素栄養に \\ おけるフスパラギンの役割を明らかにするために ${ }^{15} \mathrm{~N}$ \\ および ${ }^{14} \mathrm{C}$ 化合物を用いて二, 三の実験を行った. \\ 1. 幼果期に拈ける果皮のアスパラギン含量は果皮の \\ 全窒素含量に対し指数関係があり，果実の窒素レベルを
}


示す指標物質として利用できると考えられた.

2. 幼果実は硝酸を還元する能力がある. また無機窒 素をグルタミンやアスパラギンに合成する能力が強く, アスパラギンがグルタミンフミド公素とアスバラギン酸 から合成されると推測された.

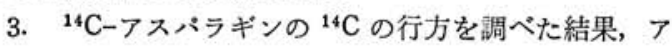
スパラギン酸, 中性及び酸性化合物, アルコール不溶化
合物および $\mathrm{CO}_{2}$ などに移行し, 他のアミノ酸への $\mathrm{C} の$ 供給源としての役割を担うと同時に, 蛋白質合成にも利 用された. また, アスバラギンの変化の様子はアスパラ ギン酸のそれと若干異なっており, アスパラギンの分解 がフスパラギナーゼ以外の酵素によってる触媒されるこ とが示唆された. 